\title{
The Roles of Mother Tongue in Enhancing English Language Acquisition in English-policy Classes
}

\author{
Dan Tam Thi Nguyen \\ Department of English Language, Faculty of Social Sciences and International Languages, Hong Bang International University, Ho Chi \\ Minh City, Vietnam
}

Email address:

tamntd@hiu.vn

\section{To cite this article:}

Dan Tam Thi Nguyen. The Roles of Mother Tongue in Enhancing English Language Acquisition in English-policy Classes. International Journal of Applied Linguistics and Translation. Vol. 6, No. 4, 2020, pp. 109-115. doi: 10.11648/j.ijalt.20200604.11

Received: September 26, 2020; Accepted: October 12, 2020; Published: October 30, 2020

\begin{abstract}
The balance of using L1, L2, and English-only policy classes has been widely explored in English language teaching. However, research on the possible and reasonable spaces for L1 in English-only policy classes among students from diverse cultural communities has been very limited. This paper reports findings of employing the Vietnamese language among Vietnamese student-teachers of English from different ethnic groups (Kinh-Vietnamese, Hoa- Chinese, and KhmerCambodian) to learn English in English-only policy classrooms. These 60 student-teachers were in the final year of their program at a teacher training college in Mekong Delta, Vietnam. The findings belong to a larger project which was designed as a qualitative case study collecting triangulated data from questionnaires, observations, textual analysis, interviews, and focus groups. Results showed that Vietnamese played significant roles in students' processing and performing tasks to adapt to the English-only classroom policy. The students' use of Vietnamese (even by non-native Vietnamese students) enabled them to work productively and facilitate the establishment of a positive and inclusive language atmosphere thanks to the proper use of Vietnamese as a tool of cognition, affection and pedagogy.
\end{abstract}

Keywords: Language Acquisition, Cultural Diversity, English-Only Policy, Language Function

\section{Introduction}

For English language learners, the only way to be fluent in English is to be immersed in the language environment. Among the ways to bring the English language environment to students is teachers' application of English-only policy in the classroom. This policy requires students to negotiate or speak English only because teachers believe that students' speaking other languages may distract their classmates' English speaking. In communicative language teaching for English language teacher education program, this policy tends to be strictly applied with the ambition to make students to be able to communicate fluently in English. However, does English-only policy work effectively in the classroom, especially with students from diverse community backgrounds? This paper reports this issue.

\section{Literature Review}

The use of L1 in foreign language learning classrooms has been discussed in different studies and from teaching approaches. In the communicative language teaching approach, L1 use is not completely forbidden, but teachers and students are advised to use L1 judiciously where possible [1]. Many second language acquisition theories have discussed the significant role of the learner's L1 in learning and teaching a foreign language. Teachers used the L1 to translate complex vocabulary and to check meanings [2]. In [3], teachers used the L1 due to the lack of time, type of textbook and parental concerns that students should achieve better results in their examinations. [4-6] also found that the L1 was employed when clarifying, checking comprehension and in classroom socialisation. [7] Found that judicious use of the L1 is necessary in teaching English in Vietnamese classrooms, and that all the participants in the study supported the use of L1 in the classes. To capture the power of using the L1, [8] suggested seven principles for using L1. These principles fell into three categories: cognitive, affective and pedagogic. As a cognitive tool, the L1 was used for L2 knowledge. As an affective tool, the L1 was used to 
create solidarity and collaboration. As a pedagogic tool, the L1 was used for time effectiveness, comprehensibility, inclusivity and contingency.

Many researchers [9-14] have stated that the L1 serves as a helpful cognitive tool. According to Vygotsky's (1976) sociocultural theory, the L1 plays a crucial role in the classrooms. [15-17] believed that the L1 facilitated L2 learning because sole use of the L2 in the classroom inhibited students from developing concepts. The L2 disconnected the students from the thoughts and concepts they had previously developed in their L1. This led to students and teachers switching between the L1 and L2. Although such codeswitching was sometimes viewed as an error and an indication of a lack of language competence, [18, 19] considered code-switching to be a pedagogical instrument for teachers. By switching into the L1, teachers could simplify the meanings, define or elaborate on the concepts of the lessons and make the important points comprehensible [20]. [21] Identified two types of code switching: methodological (translation, clarification, highlighting and time efficiency) and social (praise, encouragement, and disapproval of learners' behavior). In addition, teachers used code-switching to encourage and comfort students, to facilitate comprehension, to embed information from other subjects, to cope with discipline problems, to explain grammar, to introduce new concepts and to give a sense of achievement.

Although the L1 was found to be helpful for various reasons, some researchers do not support L1 in L2 classrooms because they believe that if teachers use the L1, students will stop processing information in the L2 and will cease practicing and communicating in L2 and shift to L1 anytime they wish [22]. In addition, using L1 has been critiqued as implying that students are working hard enough [23]. It was also noted that L1 was frequently banned in L2 classes due to English-only policies in certain countries, the rationale being that L1 use and code-switching would reduce students' exposure to L2 and lengthen delays in L2 learning in the classroom [24].

Although communicative language teaching accepts the use of the L1 in the classroom [1], there still an avoidance of the $\mathrm{L} 1$ in communicative language teaching classes [13, 2527]. This is due to the belief that students need as much exposure as possible to the target language if they are to become successful in language learning. In the Vietnamese context, the majority of studies in EFL have pointed out that because teachers used the grammar-translation method, only the L1 was spoken. In contrast, the minority of studies have claimed that in the classes in which communicative language teaching was adopted, English was spoken most of the time. However, those studies only reported the 'what', not the 'how'. As a result, this study investigates how the L1 and L2 are used in EFL classrooms at a teacher training college in the South of Vietnam.

\section{Research Design}

This project was designed as a qualitative case study that gathered rich data from multiple resources including questionnaires, observations, interviews, focus groups, field notes and textual analysis. It explored important issues around the ways in which teachers in Asia interpret the implementation of the communicative approach to teaching English in Vietnam and what forces impact on the teachers' and students' behaviours in the foreign language learning context. However, this paper is going to report data for this research question:

How does the teaching practice account for the balance between the need for meaningful communication and the students' use of L1 in the classroom?

To address this research question, I used data from both lecturer and student questionnaires to investigate how L1 was used in the classroom. These results were followed up with classroom observations, interviews and focus groups. The framework of code switching and functions of L1 were used to analyse data.

\section{Research Contexts}

The Teacher Training College, the location of the study, is a college in a remote area of Vietnam which does not have the same access to central services as do colleges in other regions such as in Hanoi, Ho Chi Minh city Bangkok or South-East Asia. It was founded in 1975, located in the rural south of Vietnam in the Mekong Delta. The college is about $60 \mathrm{~km}$ from the nearest major city in the Mekong Delta. The college has 130 staff with 78 lecturers. The college's main responsibility is training junior secondary teachers (grades 6 to 9) in all subjects for the province. In summer, it runs training courses for provincial leaders and managers. Lastly, it cooperates with different universities to offer full-time and part-time university programs for college students, but these upgraded programs usually take place during the summer.

Like other colleges and universities in Vietnam, class sizes at this Teacher Training College are large in comparison with Western institutions. The two classes of English that participated in this study each had 30 students (60 students in total), but for other subjects such as Maths or Primary Education, each class had around 40 to 45 students. Regarding the participants' ages, 41 student teachers (68\%) were between 21 and 25 years old, and $19(32 \%)$ were over 25. For ethnicity, 37 (62\%) were Kinh (Vietnamese); 19 (32\%) were Khmer (Cambodian), and 4 (7\%) were Hoa (Chinese). A total of $53(88 \%)$ were female and only 7 (12\%) were male. The main language student teachers used at home was Vietnamese (46 students $=77 \%$ ). A second language used was Khmer (14=23\%). Before starting the English Language Teacher Education Program at this College, 28 student teachers $(47 \%)$ reported that they had studied a three-yearprogram of English, which means they started to learn English at grade 10. On the other hand, 32 student teachers $(53 \%)$ had followed the seven-year-program, which means they learnt English from grade six. Their diversity of levels of achievement in English before entering this Teacher Training College was a significant challenge for both 
lecturers and students because nearly 50 per cent of the students had spent double the length of time learning English at school than the rest of the cohort.

\section{Findings}

In this study, the data obtained from student questionnaires, observations, focus groups, transcriptions and interviews showed that students worked with their peers in two different types of activities that affected L1 use. First, students sometimes worked together to prepare tasks without supervision. Second, students worked with their peers to present the results of these tasks in front of the class under supervision. In other words, there were two types of studentcentered activities: peer-to-peer preparation and student presentations. The L1 was used mainly in the former type of activity (peer-to-peer), and the L2 only was used in the latter (presentations). Code switching, in which the students' L1 was used to mediate the L2 occurred, when the students were unsupervised in preparartion activities. The use of the L1 in code switching allowed them to work effectively in the zone of proximal development. In addition, the L1 proved to be an effective tool to assist them to complete the tasks. It was also through the use of their L1 that the students revealed their identities.

\subsection{L1 in Code-switching}

Students at this Teacher Training College have a diversity of language backgrounds (Viet, Khmer and Hoa). This study was therefore interested in investigating whether code switching occurred in their language classrooms and why. It should be noted that in the Vietnamese educational system, Vietnamese is considered the only official L1 at schools. Therefore, for the Khmer students and a few of the Hoa students, Vietnamese is their second language, and English is their third. However, because of the regulation, students from these ethic groups must use Vietnamese when at college.

To investigate code switching, firstly students were surveyed about their frequency of L1 and L2 in pair and group work. The survey results showed that the majority of students (81\%) admitted that they tended to use mainly Vietnamese when discussing in pairs and groups, and provided answers in English when they spoke in front of the class. Secondly, drawing on my classroom observations, the results showed that students switched between L1 and L2 when they worked together. That is, they did not in fact mainly use Vietnamese in these activities but used both languages because they needed to note down L2 expressions for their presentations. Students always used the L2 to respond to lecturers as well as to present in front of the classes. Thirdly, this code switching in preparation but not in presentations was confirmed through data from the focus group and interviews with lecturers. In the focus group, all the Kinh students agreed that they commonly switched between Vietnamese and English. One student said:

I think it's very natural because Vietnamese language is in our blood, so whenever we discuss anything, we always mix
English and Vietnamese like that.

This student's comments reveal an interesting conflict because if the Vietnamese language was 'in their blood', how would the second major group of students, the L1-Khmer students, use Vietnamese? A representative of the Khmer students in the focus group reported that although they had all been born in Vietnam and attended Vietnamese schools, they had been brought up speaking Khmer at home and used Khmer to interact in their community and they watched and listened to Khmer entertainment. In other words, these students processed almost everything in their minds in Khmer first. Then, they translated these thoughts into Vietnamese when working with Kinh peers, and presented in English in front of the class. The Khmer student in the focus group also informed me that there were some occasions on which they did not need to think in Khmer first because many Vietnamese words were borrowed from Khmer and vice versa.

The information from this Khmer student indicates that, due to the language policy at this Teacher Training College, Khmer students used the Khmer language sub-vocally as a tool of mediation for Vietnamese, and Vietnamese was a bridging language for English. In other words, their real L1 was crucial in the learning process, but this was not acknowledged or supported by the context. [28] reported that although the population of the Khmer community was substantial, especially in the MeKong Delta, the Khmer language has been taught mainly in Khmer pagodas, and sometimes in special senior secondary schools for Khmer students. However, these senior secondary schools were a reduction of Vietnamese language programs, so only Khmer students who tend to drop out Vietnamese schools for various reasons would attend those schools. Therefore, although Khmer language use is important for Khmer students, its use is restricted to communication within families and communities.

A second reason for code switching was the language policy of the lecturers. During an interview, when I asked one of the lecturers about her feelings towards the students' code switching, she said:

Although lecturers always ask the class to speak English with each other, they tend to mix Vietnamese with English when they work in groups or pairs. If they recognise I'm going near their tables, they'll speak in English, but as soon as I move to another group, they mix Vietnamese and English again. First, I was annoyed a bit, but later, I think it was fine as long as they could speak English fluently in front of the class.

These comments indicate that lecturers understood the situation of the students' diverse language backgrounds and recognised that use of Vietnamese among peers was neccessary to allow the students to prepare in terms of language fluency, complexity and accuracy. Lecturers therefore tolerated the code switching happening.

In sum, code switching occurred only in peer-to peerpreparartion activities, when students were working without supervision. The level of L1 in this code switching depended 
on whether students continued to be supervised in passing or not. As the lecturer quoted above pointed out, when students were talking to one another, if they noticed that the lecturer was moving close to them, their discussion would be completely in L2; when they were not being observed, they would mix Vietnamese and English. The lecturers noticed these changes, but tolerated them because they understood the value of Vietnamese to students. However, as students had to ultimately perform and respond in English, they did not only-or even mainly-use Vietnamese when working together. The lecturers' language policy and the requirement of tasks meant that students only used Vietnamese when working in groups or pairs.

\subsection{Functions of $L 1$}

As noted above, code switching occured for two reasons: student diversity and classroom language policy, but when was Vietnamese used in this code switching? The data in the observations and focus groups showed that Vietnamese was used effectively in three ways: pedagogic, cognitive, and affective.

With the assistance of Vietnamese as a pedagogical tool, students had their own strategies to overcome the barriers to complete the tasks effectively to present in L2. In the focus groups, a Kinh student representative said:

I think it's very logical to mix L1 and L2 because, as you see, the time for an activity is just for three minutes maximum, if we try to think to discuss in English, we can never complete the task on time, so we often talk mainly in Vietnamese, but we take key notes in English to present.

This student's comments show that the students had very little time to work together without supervision in preparing tasks. The time restrictions inhibited students from using English during peer discussions. It took too long for them to discuss things completely in English. As a result, they chose to use Vietnamese as a pedagogical tool to overcome this time barrier because Vietnamese was the mother tongue for some students and a familiar second language for others. They therefore processed ideas faster than in English. After that, they took note in English in order to present in English in front of the class. But how did this process really unfold? The following two data excerpts taken from the analysis of the transcript of an English Literature class and British Culture class would illustrate this point.

In an English Literature class, after playing a video clip of Shakespeare's life for the class to take notes, the lecturer gave the students two minutes to work in pairs to compare their notes. After that preparation, she was intending to invite some students to share their notes in front of the class. Example 5.2.1 is part of a conversation observed between two students.

Example 5.2.1 Excerpt from peer-to-peer conversation

The students were both native speakers of Vietnamese (Kinh)

Student C: Bạn note được ý gì trong clip vâyy? (What did you note in the clip?)

Student D: Khi ông ấy was born... children ... wife, với lại lúc pass away. Còn bạn? (When he was born ... children...wife, and pass away. And you?)

Student C: Tui có thêm tên của famous works ... time live in London ... mấy khúc khác nhanh quá, take note không kip... (I had the names of famous work... time live in London ... other parts were too fast to listen to and take note)

In the conversation above, we see that under the time pressure, the two students switched between Vietnamese and English, but their Vietnamese comments contained all the important messages for processing the information, which sped up the conversation needed to complete the task. For example, the students used Vietnamese to check 'What ideas?/ The date he... The date... What about you?/ Additional detail of name... Others were too fast... Couldn't catch...'. The use of Vietnamese allowed for a faster interaction. Thus, the shared L1 worked as an affective tool, which enabled the students to save time and manage the time restriction. On the other hand, English was used to note the key terms in the lesson, which enabled the students to prepare to present in front of the class accurately. The students also sometimes used English to while discuss the video because some English words were so familiar to them that they used those words frequently as borrowed words.

In the example, most of the words in English were key vocabulary about the lesson. However, 'note', 'clip' and 'take note' were always used among these students in English because these words were so common. In general, on the one hand, the use of Vietnamese in these examples helped students work effectively, releasing them from the time pressure. On the other hand, by keeping the key words of the lesson in English, students were more able to respond to their lecturers fluently and accurately if they were invited.

Similarly, when given five minutes to work in groups to discuss the role of laws, student teachers were found to use Vietnamese as a pedagogical tool to save time, to seek agreement about what to present in front of the class, to assign jobs among the groups and to negotiate procedures to do the task. English was used to mention to key terms in the lesson, as shown in example 5.2.2.

Example 5.2.2: A discussion about the role of laws

Student A: Rồi, làm đi làm đi, vai trò của luật pháp trong xã hộ. Nhung, mày lấy giấy ghi ý chính nghe. (Okay, let's do it, let's do it. Take a piece of paper to note down main ideas what we discuss.)

Student B: Đầu tiên là laws maintain the order and stability of a country, prevent criminals... (The idea is ...)

Student C: Prevent hay Limit ta? Criminals hay crimes? Để tao check tù diển ... (...or... or...? Let me look it up)

Student A: Kệ đi, sai cô sứa. rồi gì nũa? (Not necessary, teacher will correct. What else?)

In example 5.2.2, all of the crucial messages to process the information were mainly in Vietnamese, such as assigning jobs to members and organising what should be talked about first. In addition, when a member showed the group that he was uncertain about word choice and wanted to double-check it in the dictionary, another member suggested leaving the correction for the lecturer so the preparation could move on. 
All these messages were crucial in helping the whole group move on to complete the task, and the use of Vietnamese was extremely important. On the other hand, students used English to mention key terms from the lesson about British Laws such as 'laws maintain the order and stability of a country, prevent criminals, must follow the laws strictly'.

Another significant use of Vietnamese in example 5.2.1 was to solve a semantic problem, i.e. using the language as a cognitive tool. This occurred in the last sentence of the conversation:

Student C: Student teacher hả? Ah, must follow the laws strictly because we're going to be teachers, teachers thi... làm tấm gưong cho students..

The Vietnamese word in bold has two meanings: to be a mirror (denotation), and to be a virtual model for someone (connotation). While discussing what student teachers must do to follow laws, the student may have realised that the denotation meaning of 'mirror' did not fit with the overall message she wanted like to convey. Thus she quickly switched into Vietnamese, 'làm tấm gương'.

In addition to the use of Vietnamese as a pedagogic and cognitive tool, students also used is as an affective tool in the conversation, particularly when collaborating among friends. The following conversations occurred in the Pronunciation class. The lecturer had organised the game 'slap the board'. She invited students from different groups to stand in front of the chalkboard, listen to the word she read and slap their hand on that word. The conversation in example 5.2.3 showed that when students felt eager and completely emerged in the playful atmosphere, they automatically used Vietnamese.

\section{Example 5.2.3: A game of 'slap the board'}

The lecturer wrote a list of words in different positions (full, fool, but, boot, road, rude).

Lecturer: I need two people from group A and two people from group B

Class: Quang and Ny đi cô (Call Quang and Ny, teacher). (Students laughed)

$\mathrm{S}$ : Nam thi với nũ sao đượ? (How can a girl compete with a boy?)

Lecturer: Quang and Lan please

Class: Quang ơi, đúng sát vô, sát vô. (Quang, stand closer, closer (to the board)).

Lecturer: Let's start.

Class: Cố lên Quang ơi, cố lên (Quang, come on, come one)

Lecturer: But. (boys slapping)

The male student at the chalkboard: Tói tao, mày xích ra (the girl said: My turn, step out a bit). Đập mạnh đau tay quá (The male student changed places with the girl and said: My palm was painful due to the strong slap)

Lecturer: Road.

The male student slapped on 'full', but his supporters cried loudly: đập đi Quang, đập đi (Quang, slap, slap it)

The male student was confused and turned back to his group: Nghe rõ ràng chũ full mà? Đập chũ nào nũa? (I heard clearly the word 'full'. What is the other word to slap on?)

Lecturer: Boot.

Class: Quá hay, quá hay (Very good, very good).

Lecturer: Last one...

Class: Trời, nó đứng nhìn ngo ngác vậy chắc sang thu mói đập được một chĩ. (Oh dear, if he looks so puzzled like that, he'll slap another word next autumn (it will take him forever to slap)).

Lecturer: Rude.

The male student slapped on the word 'Road'. All of his group laughed loudly and slapped on the tables.

The male student looked at his friend and realised his friend got the right word: Ủa, tù rude bên kia móti đúng hả? (Oops, the word 'rude' is the right one?)

His friends in the group shouted and laughed: Thô $i$, quê quá, quê quá. Về đi, về đi (Oh dear, so embarrassing, so embarrassing, come back to your seat, come back).

This conversation shows that Vietnamese was used as an affective tool for solidarity and collaboration. The use of Vietnamese facilitated easy interactions among the students and developed team work. In addition, the conversation above also demonstrated the language policy in the classroom again, which was that the lecturers avoided using Vietnamese in the classroom. Whenever students spoke in Vietnamese, even in front of her while playing games, the lecturer accepted their use of Vietnamese, but she always used English to moderate the game right until the end.

A further aspect of the use of Vietnamese as an affective tool was when students naturally used registers of Vietnamese among friends which revealed their personal backgrounds and their closeness with friends in the group. Vietnamese speakers can draw on a wide range of registers to address people, depending on their social relationships, family backgrounds, levels of formality or attitudes towards others. The use of particular registers in Vietnamese means that many details about the speakers' personal backgrounds can be inferred. This point emerged in this study when students used Vietnamese in their code switching in examples 5.2.1 and 5.2.2 above.

In the conversation in example 5.2.1, students' personal backgrounds were revealed through the use of personal pronouns when the students communicated with one another: bạn (you) and tui (I). In Vietnamese culture, when two people of the same age talk to one another, the formal and most common pronouns used are 'bạn'/ 'cậu' (you) and 'tôi' / 'tớ' (I) instead of 'tui'. Although both 'tôi' and 'tui' have the same meaning as 'I', the latter implies the identity of the speakers. First, it is a dialectal form, used only in the southern region of Vietnam. Second, it is used commonly in rural areas of the south, where farming is the main means of livelihood. Third, it is used only when two speakers are more than acquaintances. Therefore, the use of Vietnamese in example 5.2.1 reveals that: (i) the two students were closer than mere acquaintances; (ii) one student was born and raised in a farming family; and (iii) that student's home town was in the south of Vietnam.

However, the use of Vietnamese in the conversation in 5.2.2 
revealed something a little different from 5.2.1. In example 5.2.2 the male student referred to himself as 'tao' (I), and referred to the female students as 'mày' (you). In Vietnamese culture, the standard ways for a male to address a female are to say her name if the speaker knows it or to use the pronoun 'bạn'. However, although the boy used her name, 'Nhung', he did so to indicate the specific person he was talking to and assigning the work to do. In addition, the pair of words are typical pronouns of the Southern region of Vietnam, and they are only used when people in the conversation are extremely close or have been good friends for a long time. If a person employed these pronouns in a conversation with people he/she was not close to, the speaker would be considered very rude and uneducated. If these two registers are used inappropriately, they have potential to cause a misunderstanding by implying that the speaker is angry with the listener. Therefore, the use of Vietnamese in example 5.2.2 indicates that: (i) the male and female students were very close to each other; and (ii) both of them reside in the south of Vietnam.

In brief, this section has presented the ways in which students used Vietnamese as a cognitive, affective and pedagogical tool in the classroom. Students used Vietnamese as a cognitive tool to put into their familiar language words they did not know in English. They used Vietnamese as an affective tool to facilitate easy interactions among peers, develop team work and reveal their personal backgrounds. They used Vietnamese as a pedagogic tool to overcome the time constraints and to complete set tasks on time.

\section{Discussions and Conclusion}

The findings reported in this paper showed that the students had their own strategies for using Vietnamese and English. The students were found to use Vietnamese when talking amongst themselves, but they made notes in English and used English when presenting in front of the class. The students were found to use Vietnamese as a cognitive tool [8] to deal with the difficulty of finding semantic equivalents. They also used Vietnamese as a pedagogic tool for time efficiency and comprehensibility [8]. In other words, they used Vietnamese to overcome the time pressure that their lecturers imposed, and they used Vietnamese among their peers to speed up the learning process so that they all fully understood the requirements of tasks.

The final finding about the students' use of Vietnamese was to note that it functioned also as a tool of solidarity and affective relations [8]. When the KADI students used Vietnamese amongst themselves, the register characteristics of their language expressed their personal backgrounds and reinforced their social relationships. A rich variety of forms of address and ways of speaking in Vietnamese express hierarchy, closeness, relationships, attitudes, geographic origins and social positions. Some registers in Vietnamese are used only by specific groups of people in specific regions. Through the use of different registers, speakers revealed information about their origin, residence or occupations. When using Vietnamese, students in this study revealed their long-term residency in the rural south of Vietnam. Their language use also indicated that they had been raised in families with farming as their main livelihood. In addition, the use of Vietnamese in some of language games allowed students to display their excitement and created a playful atmosphere when the students encouraged and supported each other. Looking back at notions of the British and American English standards that those students are striking for, it can be seen that the student teachers in this study were struggling with their personal and professional identities as non-native teachers of English. On the one hand, as non-native speakers of English the students found it helpful and felt comfortable using Vietnamese to complete English tasks. On the other hand, they were also striving to reach native-like standards of English because they were going to become non-native teachers of English.

This study's findings about the use of Vietnamese showed that Vietnamese was both a tool the students used to overcome linguistic problems and a strategy for them to deal efficiently with the need to process information. If viewed through a pedagogic lens, these findings raise issues for foreign or second language teachers, especially in the Vietnamese context. In large classes, if teachers pay close attention to the students' use of Vietnamese when they express their social and personal identities, they may better understand their students' backgrounds. This can be useful for them in planning a specific teaching method or an adaptation in their context. In addition, when students reveal the degrees of intimacy in their relationships with their classmates, teachers can use this information to make decisions about how best to group the students. In Confucian heritage classrooms, students have a tendency to work more effectively with friends who are closer to them. This means there would be a strong possibility that students will not work as well with peers with whom they are less familiar. Understanding the students' backgrounds may allow the teacher to vary the groups in his or her classroom, which may be a useful pedagogical strategy for teachers to consider, according to their teaching goals.

\section{References}

[1] J. C. \&. R. T. S. Richards, Approaches and methods in language teaching, Cambridge university press., (2014).

[2] J. C. \&. N. H. Campa, "The amount, purpose, and reasons for using L1 in L2 classrooms," Foreign Language Annals, vol. 42, no. 4, p. 742-759., 2009.

[3] L. \&. A. S. Mahmoudi, " The use of Persian in the EFL classroom-The case of English teaching and learning at preuniversity level in Iran," English Language Teaching, vol. 4, no. 1 , p. 135,2011

[4] A. Sampson, "Learner code-switching versus English only," ELT journal, vol. 66, no. 3, p. 293-303, 2011.

[5] F. \&. N. G. Copland, " L1 to teach L2: Complexities and contradictions.," ELT journal, vol. 65, no. 3, p. 270-280., 2010 . 
[6] M. A. Gulzar, "Code-Switching: Awareness about Its Utility in EFL/ESL Classroom Discourse.," Bulletin of Education and Research, vol. 32, no. 2, p. 1-14, 2010.

[7] K. H. K. Anh, " Use of Vietnamese in English Language Teaching in Vietnam: Attitudes of Vietnamese University Teachers," English Language Teaching, vol. 3, no. 2, p. 119128, 2012.

[8] R. Forman, First and second language use in Asian EFL, Multilingual Matters, 2016.

[9] A. Lin, "Classroom code-switching: Three decades of research.," Applied Linguistics Review, vol. 4, no. 1, p. 195218, 2013.

[10] E. Macaro, "Analysing student teachers' codeswitching in foreign language classrooms: Theories and decision making.," The Modern Language Journal, vol. 85, no. 4, p. 531-548, 2001.

[11] A. N. J. \&. G. N. Pakdaman-Savoji, "The conceptualisation of cognitive tools in learning and technology: A review.," Australasian Journal of Educational Technology, vol. 35, no. 2, 2019.

[12] J. Z. J. C. Y. A. C. W. K. A. \&. L. P. Legault, "Immersive virtual reality as an effective tool for second language vocabulary learning.," Languages, vol. 4, no. 1, p. 13, 2019.

[13] J. Y. D. L. Q. \&. C. Y. Shin, "An updated review on use of L1 in foreign language classrooms," Journal of Multilingual and Multicultural Development, vol. 41, no. 5, pp. 406-419, 2020.

[14] P. Z. F. Y. A. \&. Z. X. Li, "Language History Questionnaire (LHQ3): An enhanced tool for assessing multilingual experience," Bilingualism: Language and Cognition, pp. 1-7., 2019.

[15] D. C. Skinner, "Access to meaning: The anatomy of the language/learning connection," Journal of Multilingual \& Multicultural Development, vol. 6, no. 5, p. 369-388, 1985.

[16] K. \&. M. E. McManus, " Using explicit instruction about L1 to reduce crosslinguistic effects in L2 grammar learning: Evidence from oral production in L2 French," The Modern Language Journal, vol. 103, no. 2, pp. 459-480, 2019.

[17] C. A. Lenkaitis, "Technology as a mediating tool: Videoconferencing, L2 learning, and learner autonomy.," Computer Assisted Language Learning, vol. 33, no. 5-6, pp. 483-509, 2020.
[18] V. Cook, "Using the first language in the classroom.," Canadian modern language review, vol. 53, no. 3, p. 402-423, 2001.

[19] P. Gardner-Chloros, "Contact and code-switching.," The handbook of language contact, pp. 181-199, 2020.

[20] S. S. D. K. \&. S. B. M. M. Shekhar, "An effective cybernated word embedding system for analysis and language identification in code-mixed social media text," International Journal of Knowledge-based and Intelligent Engineering Systems, vol. 23, no. 3, pp. 167-179, 2019.

[21] L. C. M. C. P. B. B. d. J. A. P. M. d. H. A. \&. S. N. O. Pablos, " Adjective-noun order in Papiamento-Dutch code-switching," Linguistic Approaches to Bilingualism, vol. 9, no. 4-5, pp. 710-735, 2019.

[22] S. \&. A. A. B. Tasçi, "L1 Use in L2 Teaching: The Amount, Functions, and Perception towards the Use of L1 in Turkish Primary School Context," International Online Journal of Education and Teaching, vol. 7, no. 2, pp. 655-667, 2020.

[23] K. Ford, "(2009). Principles and practices of L1/L2 use in the Japanese university EFL classroom," JALT journal, vol. 31, no. 1, p. 63-80, 2009.

[24] I. \&. R. H. Aizawa, "An analysis of Japan's English as medium of instruction initiatives within higher education: the gap between meso-level policy and micro-level practice," Higher Education, vol. 77, no. 6, pp. 1125-1142, 2019.

[25] Y. G. Butler, " The implementation of communicative and task-based language teaching in the Asia-Pacific region," Annual Review of Applied Linguistics, vol. 31, p. 36-57, 2011.

[26] V. C.-M. G. P.-T. E. \&. P. F. Toro, "The Use of the Communicative Language Teaching Approach to Improve Students' Oral Skills," English Language Teaching, vol. 12, no. 1, pp. 110-118, 2019.

[27] H. M. A. R. Al Balushi, "Language Teaching Research Quarterly.," Language Teaching Research, vol. 16, pp. 56-70, 2020 .

[28] T. Hoang, "Nơi duy nhất trong cả nước đào tạo ngành ngôn ngữ Khmer.," 2017. [Online]. Available: Retrieved from http://dantri.com.vn/giao-duc-khuyen-hoc/noi-duy-nhat-trongca-nuoc-dao-tao-nganh-ngon-ngu-khmer20170301072316167.htm. [Accessed 2017]. 